\title{
CORPORATE MEMORY: A MEMORY COMPACTION APPARATUS TOWARDS MALAYSIA'S PROMINENT COMPANIES TRANSPARENT GOVERNANCE
}

\author{
Razifah Othman 1,2,3*, Rahimah Abd Rahman', Aflah Isa ${ }^{2}$, Zailani Shafie ${ }^{3}$, Amirah Abu Hassan $^{3}$ \\ ${ }^{1}$ Faculty of Information Management Perbadanan Usahawan Nasional Berhad, Kuala Lumpur \\ ${ }^{2}$ Faculty of Business Management, UiTM Johor \\ ${ }^{3}$ Faculty of Information Management, ${ }^{1 *}$ University Teknologi Mara Cawangan Negeri Sembilan, Kampus Rembau, Negeri Sembilan, Malaysia \\ *Corresponding Author Email: razif879@,uitm.edu.my
}

This is an open access article distributed under the Creative Commons Attribution License, which permits unrestricted use, distribution, and reproduction in any medium, provided the original work is properly cited.

\section{ARTICLE DETAILS}

\section{Article History:}

Received 26 November 2018

Accepted 25 January 2019

Available online 19 Febraury 2019

\section{ABSTRACT}

This study significances to analyze the twosome relationship between Corporate Memory (CM) and Information Communication Technology (ICT) among most prominent companies in Malaysia . It also provides empirical evidence and confirms the results of past researchers that CM practices such as knowledge sharing are positively and significantly related to ICT. This research implies that when companies apprehend the significance of CM, there is a great possibility for it to flourish in harvesting the full value of transparent governance. Survey data from four diverse companies were obtained to examine the relationships between CM and ICT facilities and it's impact in conveying daily tasks.

\section{KEYWORDS}

Corporate Memory, Information Communication Technology, Knowledge Management, Knowledge Sharing, Transparent governance

\section{INTRODUCTION}

The connotation of data, Information and processed knowledge as one of a perilous business capital has assured many organizations to examine and manage its significance while without noticed has initiating Knowledge Management (KM) efforts. This spontaneously symbolized efficiencies, good reputation and systematic management. The advances of Information Communication Technology (ICT) enables information and knowledge to be manage, access, retain and circulate better. At the moment, companies in Malaysia are employing ICT to facilitate business activities while broadening their knowledge span and employ it as a strategic decision-making tool. However, different concepts concerning usage and best practices of ICT do create standards and affecting organization's performance. Major organizational transformations are foreseeable when ICT integrated into employment functions assisting workers in cutting through overbearing matters that engraved as translucent governance. On a global perspective, we believe that the ultimate goal of every organization is to be a competitive power that maximizes their knowledge potential besides obtain promising profits. Therefore, every nature of business doings was suggested to incorporate with Corporate Memory (CM). This study intends to identify the CM practices at Malaysia's leading companies who utilize ICT in their day to day activities. The context of the study is referring to three side points as variables namely ICT facilities and design, CM practices, and CM impacts. Multimedia Super Corridor (MSC) Malaysia, Multimedia University Cyberjaya (MMU), Malaysia External Trade Development Corporation (MATRADE) and Petroliam Nasional Berhad (PETRONAS) selected as the research settings. These companies are foretelling as leading companies with diverse portfolios but applying technologies in producing and enhancing their deliverables and services.

\section{PROBLEM STATEMENT}

It is difficult to recapture the loss of memory solution to exacerbate the major skills further into significant recruitment that will reach beyond simply capturing loads of information, access it, understandable and put into context. The prominence to ascertain valuable knowledge and succession planning generally done via mentoring culture and some companies developed a system to excavate tacit knowledge through sharing session or depositing important document into a system as Knowledge bank or Corporate Memory (CM). However, there are some previous literature indicates potential reasons for the failures of $\mathrm{CM}$ initiatives. Impulsion for flexible labor market for instance levied corporate amnesia on organizations from extracting individuals memories, corporate memory's veracity as there are no knowledge transfer programs be done and lost due to staff exit or exchange. Its importance to an organization to apply it, segregate the experiential learning discipline or project's evidence-based practice. Post-project assessments, via business intelligence system, should be dispersed as a part of learning and managed by a knowledge management-oriented community of practice (COP). Knowledge transfer practice through mechanism alike training, routines, observation of experts, standard operating procedures (SOP), manuals and databases by many organizations in Malaysia examined as not be placed into a reputable knowledge repository physically or systematically (Nor Aziati and Juhana Salim (2011)

\section{RESEARCH OBJECTIVES}

1. To investigate the determinant of corporate memory in serving the activities and needs of knowledge workers.

2. To analyze the impacts of corporate memory in formulating useful information and knowledge to be applied in the organization's service delivery.

\section{LITERATURE REVIEW}

The concept of corporate memory has popularized more than 20 years and known with many definitions and terms. Corporate memory (CM) is not just a platform to gather and preserve knowledge but also act as a medium for knowledge sharing activities [1]. Based on Knowledge Management (KM) and business practices, the types of knowledge are usually classified 
into two categories, namely tacit and explicit knowledge. This theoretical cornerstone commonly defined that explicit knowledge as a knowledge that is formalized and codified while tacit knowledge is a knowledge embodied in people based on their mental models, attitude, cultural beliefs, values, as well as skills, expertise, and experiences [2-4]. On an auxiliary argument, embedded knowledge was introduced as the third types of knowledge. It is referred to the knowledge exist in in organization's routines, processes, products, culture, structures or artifacts [5]. Storey and Kahn emphasized the role of corporate memory in policy making and decision making executions [6]. Research in information systems has placed a heavy emphasis on the role of technology-based memory systems in providing support for problem solving and decision making [7-9]. Most of it are conceptual and concentrated on the design principles of a technology-based corporate memory systems. Therefore, the ultimate goal of this research is to investigate how ICT can be used to enhance corporate memory while narrowing the interpretation about the concept of CM as an explicit, disembodied representation of the information and knowledge in an organization which covers knowledge about products, production progressions, customers, selling strategies, financial results, strategic plans and etc.

\section{RESEARCH METHODS}

In essence, this study employed a mixed model research design integrating quantitative and qualitative approaches by using a questionnaire survey that included closed-ended questions. In addition to these, in-depth interviews with 23 IT administrators from each organization were conducted in order to identify the practice setting and the efficiencies of applying corporate memory within organization workforce for their routine knowledge sharing activities. The results are concluded into three

(3) sections respectively as:

(i) ICT facilities and designs,

(ii) Knowledge sharing methods,

(iii) Corporate Memory impacts

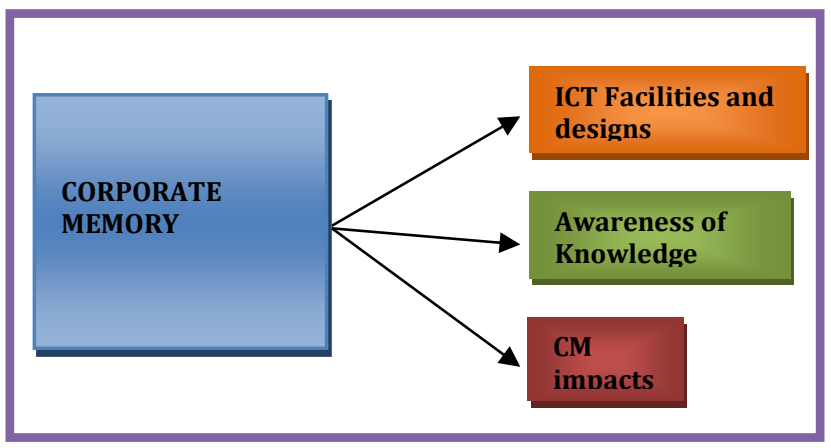

Figure 1: Research framework

Table 1: Site and population sampling

\begin{tabular}{|l|l|l|l|l|l|}
\hline Site & Portfolio & Group & $\begin{array}{l}\text { Population size } \\
\text { (department) }\end{array}$ & $\begin{array}{l}\text { Sample } \\
\text { size }\end{array}$ & CM application \\
\hline MSC Malaysia & ICT Industry & ICT professionals & $\mathrm{n} 17$ & $\mathrm{~s} 15$ & $\begin{array}{l}\text { MSCInternet.com } \\
\text { (Intranet portal) } \\
\text { email system }\end{array}$ \\
\hline $\begin{array}{l}\text { Multimedia } \\
\text { University Cyberjaya } \\
\text { (MMU) }\end{array}$ & Education Industry & Academicians & $\mathrm{n} 16$ & $\mathrm{~s} 13$ & $\begin{array}{l}\text { Online.mmu.edu.my } \\
\text { (Intranet portal) } \\
\text { email system }\end{array}$ \\
\hline $\begin{array}{l}\text { Malaysia External } \\
\text { arade Development } \\
\begin{array}{l}\text { Corporation } \\
\text { (MATRADE) }\end{array}\end{array}$ & $\begin{array}{l}\text { Trade Promotion } \\
\text { Agency }\end{array}$ & Product support & $\mathrm{n} 14$ & $\mathrm{~s} 12$ & $\begin{array}{l}\text { MyMartrade } \\
\text { portal) and email system }\end{array}$ \\
$\begin{array}{l}\text { Petroliam Nasional } \\
\text { Berhad (PETRONAS) } \\
\text { Carigali }\end{array}$ & $\begin{array}{l}\text { Upstream and } \\
\text { downstream oils and } \\
\text { gas }\end{array}$ & $\begin{array}{l}\text { ICT professionals and } \\
\text { Engineers }\end{array}$ & $\mathrm{n} 12$ & $\mathrm{~s} 10$ & $\begin{array}{l}\text { Enterprise } \\
\text { Management (ECM) and } \\
\text { email system }\end{array}$ \\
\hline
\end{tabular}

\subsection{Sampling techniques for survey}

The total correspondence is 50 out of 58.58 is the sum of random department's staff from MSC, MMU, MATRADE, and PETRONAS Carigali.

\subsection{Interview method}

This discussion explores essential technology requirements and trends for the organization and learns how the right technology allows them to gain a competitive advantage with insight into the latest technology in boosting overall productivity and reshape standards of operations. The analyzed and auxiliary topics of the interview covered particular key points as below and parallel with ICT Security Policy Version 2.0, ICT CircularSoftware Prohibition for the Use of P2P and Guidelines on Information Telecommunication Technology (ICT) Procurement. The circular deployed by this research to gain general understanding from system administrator point of view on the function and usage of ICT, measuring management and distributed information quality, along with issues and challenges faced in managing ICT tools.

Table 2: Interview Indicators

\begin{tabular}{|c|c|c|}
\hline No & Questions & Key indicators \\
\hline 1. & $\begin{array}{l}\text { Typical Operational Pains and } \\
\text { Technical Issues }\end{array}$ & $\begin{array}{l}\text { (a) Identifying and analysing typical operational thoroughness for the organization such as high staff } \\
\text { turnover, timely access to files, information capture and document accuracy } \\
\text { (b) Asking the right questions at the beginning of a technology event to determine the inefficiency of } \\
\text { the manual approach }\end{array}$ \\
\hline 2. & Hardware and software & $\begin{array}{l}\text { (a) Types of hardware and software } \\
\text { (b) Features of the hardware and software }\end{array}$ \\
\hline 3. & Content Management System & $\begin{array}{l}\text { (a) The key features: Contact database, client accounts, remote access } \\
\text { (b) Differentiation between content and context of document }\end{array}$ \\
\hline 4. & Cloud Services & $\begin{array}{l}\text { (a) Highlighting the usefulness and risk of online storage, calendar, email and instant messenger } \\
\text { services } \\
\text { (b) Improving internal / external communication with Corporate Extranet Instant Messenger System }\end{array}$ \\
\hline 5. & $\begin{array}{l}\text { Computer } \quad \text { Security } \\
\text { Protection }\end{array}$ & $\begin{array}{l}\text { (a) How do they create security risks? } \\
\text { (b) The best practices against computer security risk }\end{array}$ \\
\hline 6. & Impact from the technology & $\begin{array}{l}\text { (a) How it revolutionized the way of the organization to conduct their business } \\
\text { (b) Positive and negative impact }\end{array}$ \\
\hline
\end{tabular}


Table 3 showed that the total Cronbach's $\alpha$ (alpha) for dependent variables and independent variables are highly correlated. Based on the formula for reliability analysis, the reliability for this research is very good due to Cronbach's Alpha .866 whereby N of items is 33 are reliable to ask

Reliability Statistics

Cronbach's Alpha

.866

\begin{tabular}{r|r} 
Cron \\
\hline 866 \\
\hline
\end{tabular}

Table 3: Reliability Statistics

\begin{tabular}{l|l} 
onbach's Alpha & Cronbach's Alpha
\end{tabular}
to the respondents. This shows that our primary data can be rely on and categorized as a good outcome that meets with our variables and objectives of the research.

\section{ICT FACILITIES AND DESIGN}

Table 4: ICT Facilities and design

\begin{tabular}{|c|c|c|c|c|c|c|}
\hline & & $\begin{array}{l}\text { Top management } \\
\text { support use of } \\
\text { CM }\end{array}$ & $\begin{array}{l}\text { Top management } \\
\text { provide enough } \\
\text { funds for CM }\end{array}$ & $\begin{array}{l}\text { Hardware and software } \\
\text { provided are help in } \\
\text { documentation of CM }\end{array}$ & $\begin{array}{l}\text { Top management } \\
\text { provide training of } \\
\text { using ICT in CM } \\
\text { documentation }\end{array}$ & $\begin{array}{l}\text { Training } \\
\text { provided by top } \\
\text { management is } \\
\text { very effective and } \\
\text { helping in CM }\end{array}$ \\
\hline $\begin{array}{l}\text { Top management } \\
\text { support use of CM }\end{array}$ & $\begin{array}{l}\text { Pearson } \\
\text { Correlation Sig. } \\
\text { (2-tailed) N }\end{array}$ & $\begin{array}{l}1 \\
50 \\
\end{array}$ & $\begin{array}{l}.287^{\prime} \\
.043 \\
50\end{array}$ & $\begin{array}{l}.663^{\prime \prime} \\
.000 \\
50 \\
\end{array}$ & $\begin{array}{l}.595 " \\
.000 \\
50 \\
\end{array}$ & $\begin{array}{l}.691^{\prime \prime} \\
.000 \\
50 \\
\end{array}$ \\
\hline $\begin{array}{l}\text { Top management } \\
\text { provide enough } \\
\text { funds for CM }\end{array}$ & $\begin{array}{l}\text { Pearson } \\
\text { Correlation Sig. } \\
\text { (2-tailed) N }\end{array}$ & $\begin{array}{l}.287^{\prime} \\
0.43 \\
50\end{array}$ & $\begin{array}{l}1 \\
50\end{array}$ & $\begin{array}{l}.647 " \\
.000 \\
50\end{array}$ & $\begin{array}{l}.551 " \\
.000 \\
50\end{array}$ & $\begin{array}{l}.695^{\prime \prime} \\
.000 \\
50\end{array}$ \\
\hline $\begin{array}{lr}\text { Hardware } & \text { and } \\
\text { software provided } \\
\text { are help in } \\
\begin{array}{ll}\text { documentation of } \\
\text { CM }\end{array} \\
\end{array}$ & $\begin{array}{l}\text { Pearson } \\
\text { Correlation Sig. } \\
\text { (2-tailed) N }\end{array}$ & $\begin{array}{l}.663^{\prime \prime} \\
.000 \\
50\end{array}$ & $\begin{array}{l}.647 " \\
.000 \\
50\end{array}$ & $\begin{array}{l}1 \\
50\end{array}$ & $\begin{array}{l}.718^{\prime \prime} \\
.000 \\
50\end{array}$ & $\begin{array}{l}.663 " \\
.000 \\
50\end{array}$ \\
\hline $\begin{array}{l}\text { Top management } \\
\text { provide training of } \\
\text { using ICT in CM } \\
\text { documentation }\end{array}$ & $\begin{array}{l}\text { Pearson } \\
\text { Correlation Sig. } \\
\text { (2-tailed) N }\end{array}$ & $\begin{array}{l}.595^{\prime \prime} \\
.000 \\
50\end{array}$ & $\begin{array}{l}.551 " \\
.000 \\
50\end{array}$ & $\begin{array}{l}.718^{\prime \prime} \\
.000 \\
50\end{array}$ & $\begin{array}{l}1 \\
50\end{array}$ & $\begin{array}{l}.681 " \\
.000 \\
50\end{array}$ \\
\hline $\begin{array}{l}\text { Training provided } \\
\text { by top management } \\
\text { is very effective and } \\
\text { helping in } \mathrm{CM}\end{array}$ & $\begin{array}{l}\text { Pearson } \\
\text { Correlation Sig. } \\
\text { (2-tailed) N }\end{array}$ & $\begin{array}{l}.691^{\prime \prime} \\
.000 \\
50\end{array}$ & $\begin{array}{l}.675^{\prime \prime} \\
.000 \\
50\end{array}$ & $\begin{array}{l}.663^{\prime \prime} \\
.000 \\
50\end{array}$ & $\begin{array}{l}.681 " \\
.000 \\
50\end{array}$ & $\begin{array}{l}1 \\
50\end{array}$ \\
\hline
\end{tabular}

In ICT facilities, factors based on Table 4 showed that the strongest correlation is between top management provide training of using ICT in corporate memory and hardware and software provided are help in documenting the corporate memory .718. So these two shows that management should support hardware and software trainings so that they can master new adapted software and hardware. Creating a comprehensible IT infrastructure for $\mathrm{CM}$ in scattered environments is an intricate task. Nevertheless, managers and professionals have to be savvy with the embryonic ICT technologies available and devouring a solid foundation in technical skills in order to fit with their CM repository.

\section{CORPORATE MEMORY IMPACT}

Table 5: Corporate Memory Impact

\begin{tabular}{|c|c|c|c|c|c|c|}
\hline & & $\begin{array}{l}\text { CM helps in generate } \\
\text { idea compare } \\
\text { searching information } \\
\text { searching by using ICT } \\
\text { applications }\end{array}$ & $\begin{array}{l}\text { Top } \\
\text { management } \\
\text { provide enough } \\
\text { funds for CM }\end{array}$ & $\begin{array}{l}\text { ICT usage helps } \\
\text { in CM } \\
\text { management }\end{array}$ & $\begin{array}{l}\text { Time for } \\
\text { decision } \\
\text { making is faster } \\
\text { with CM }\end{array}$ & $\begin{array}{l}\text { CM easy to access } \\
\text { with database } \\
\text { storage }\end{array}$ \\
\hline $\begin{array}{l}\text { CM helps in generate idea } \\
\text { compare searching } \\
\text { information searching by } \\
\text { using ICT applications }\end{array}$ & $\begin{array}{l}\text { Pearson } \\
\text { Correlation Sig. } \\
\text { (2-tailed) N }\end{array}$ & $\begin{array}{l}1 \\
50\end{array}$ & $\begin{array}{l}.40 .3^{\prime} \\
.004 \\
50\end{array}$ & $\begin{array}{l}.127 \\
.379 \\
50\end{array}$ & $\begin{array}{l}.145 \\
.314 \\
50\end{array}$ & $\begin{array}{l}.521 " \\
.000 \\
50\end{array}$ \\
\hline $\begin{array}{l}\text { Top management provide } \\
\text { enough funds for CM }\end{array}$ & $\begin{array}{l}\text { Pearson } \\
\text { Correlation Sig. } \\
\text { (2-tailed) N }\end{array}$ & $\begin{array}{l}.403^{\prime} \\
0.04 \\
50 \\
\end{array}$ & $\begin{array}{l}1 \\
50\end{array}$ & $\begin{array}{l}.403^{\prime \prime} \\
.004 \\
50\end{array}$ & $\begin{array}{l}.456 " \\
.001 \\
50\end{array}$ & $\begin{array}{l}.601 " \\
.000 \\
50\end{array}$ \\
\hline $\begin{array}{l}\text { ICT usage helps in CM } \\
\text { management }\end{array}$ & $\begin{array}{l}\text { Pearson } \\
\text { Correlation Sig. } \\
(2 \text {-tailed) N }\end{array}$ & $\begin{array}{l}.127 \\
.379 \\
50 \\
\end{array}$ & $\begin{array}{l}.403 " \\
.004 \\
50 \\
\end{array}$ & $\begin{array}{l}1 \\
50 \\
\end{array}$ & $\begin{array}{l}.565 " \\
.000 \\
50 \\
\end{array}$ & $\begin{array}{l}.674 " \\
.000 \\
50 \\
\end{array}$ \\
\hline $\begin{array}{l}\text { Time for decision making } \\
\text { is faster with } \mathrm{CM}\end{array}$ & $\begin{array}{l}\text { Pearson } \\
\text { Correlation Sig. } \\
\text { (2-tailed) N }\end{array}$ & $\begin{array}{l}.145 \\
.314 \\
50 \\
\end{array}$ & $\begin{array}{l}.456 " \\
.001 \\
50 \\
\end{array}$ & $\begin{array}{l}.565^{\prime \prime} \\
.000 \\
50 \\
\end{array}$ & $\begin{array}{l}1 \\
50 \\
\end{array}$ & $\begin{array}{l}.533 " \\
.000 \\
50 \\
\end{array}$ \\
\hline $\begin{array}{l}\text { CM easy to access with } \\
\text { database storage }\end{array}$ & $\begin{array}{l}\text { Pearson } \\
\text { Correlation Sig. } \\
\text { (2-tailed) N } \\
\end{array}$ & $\begin{array}{l}. .521 " \\
.000 \\
50 \\
\end{array}$ & $\begin{array}{l}.601 " \\
.000 \\
50 \\
\end{array}$ & $\begin{array}{l}.674^{\prime \prime} \\
.000 \\
50 \\
\end{array}$ & $\begin{array}{l}.533^{\prime \prime} \\
.000 \\
50 \\
\end{array}$ & $\begin{array}{l}1 \\
50 \\
\end{array}$ \\
\hline
\end{tabular}

Table 5 showed that the strongest correlation is between ICT usage helps in management and corporate memory easy to access with database storage with .674 . The database helps in managing information and makes users easy to access data. The most efficient correlation is on factor knowledge sharing between $\mathrm{CM}$ can help distribute information faster and effective, and knowledge sharing of CM can expand with information from others Institute with 987 . Based on the entire figure above showed that corporate memory should be applied in the organization because of its significant especially from the factor of knowledge sharing. It is proven that CM provides fast distribution and effective information because all information will be organized and preserve. Thus, act as an essential prerequisite for effective action, decision-making, and learning processes. 


\section{RECOMMENDATIONS}

\subsection{Cultivating Knowledge sharing and CM culture}

Memory is a rich metaphor that must be maintained by an organization constitute an atlas of its precedent that contains enormous amounts of information, lessons, and achievements $[10,11]$. The pose taken by this research is that organizational expertise can act as a capital of modest improvement. The awareness towards CM efficiency and effectiveness permit different outcomes. By blending $\mathrm{CM}$ tools into workers processes despite management level will certainly span functions of departments and organizations. However, it is predominantly difficult due to individual acceptance and organizational culture. Therefore, top management intervention is required as a leaning point amid potential success and failure in fortifying business continuity management projects while fostering human and technology [12]. It has become a widely recognized fact that most failures in ICT implementation and development are indeed due to weak management. Management effort in conferring sufficient budget for purchasing tools for ICT enhancement, along with organizing trainings and workshops for staffs regarding ICT applications provides retentive capacities of personal and organizational prerequisites, and the mechanisms' impacts will enrich to organizational efficacies

\subsection{Infrastructure}

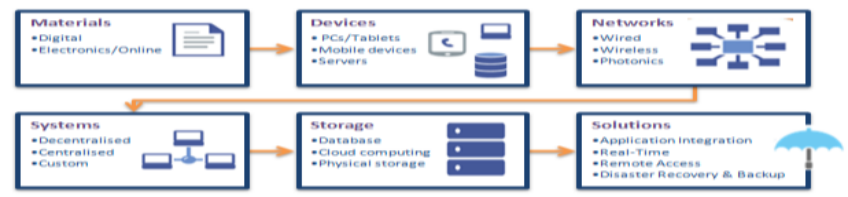

Figure 2: Components of Corporate Memory

Based on Figure 2, coalesce of innovation and technology are demanded and proliferate as a main apparatus of success for an organization in today's viable segments. The reason is that companies with the capacity to innovate will be able to adapt with environmental challenges faster and better than non-innovative companies [13]. As shown in above figure, organizational memory and technology infrastructure is signified by sundry aspects of an organization covering the organization's culture, production processes and work procedures, structures, physical work settings and preserving various formats of information, knowledge and experience [10]. All the material intended to be embedded within the corporate memory must be identified and analyzed besides determining its data type and importance to be converted as and output of the repository. Further, different technology infrastructures were used for retention constitution. Classifying and storing organization's manuals, databases, filing systems, can be done via cloud computing or physical technology. Tools to access the system also variant from traditional PCs to tablets and mobile devices which also necessitate compatible software. The network is also an important feature for accessing the repository base on individual's preferences either wired or wirelessly. Further, the CM also must continually update and analyzes in order to spawn new tributary of information, while intensifying knowledge Effective capture and reuse of less tangible knowledge assets within the organization, can be enhanced by using common and shared vocabulary thus also represented with ontologies [14].

\section{SPECIFIC OR POTENTIAL APPLICATIONS}

1. At a micro-perspective, the employment of a corporate memory is to profit organizations to improve the quality and efficiency of dynamic opportunistic project management and coordination based on previous experiences

2. The corporate learning system mentioned also will act as a selfeducation foundation for employees to access others' tacit knowledge and experiences.

\section{CONCLUSION}

There are few factors that can be concluded based on this study. The first is a generational difference between baby boomers and the Generation (Gen Y). It seems obvious that Gen Y who is called "connected generation" get in touch almost with computer applications thus have no problem utilizing corporate memory compared to baby boomers who reluctant to change. As an idea, readiness for organizational members' to change and share resolutions and belief in their collective capability should be positively consider by using three key determinants of implementation capability which are task demands, resource availability, and situational factors. When organizational readiness for change is high, organizational members will induct change, initiate bigger effort, and shows additional cooperative behavior. Next factor would probably lack motivation incentives especially for middle and upper management to utilize the system. As those who believed have the power and authority, this group would of course easily instruct and order their subordinates to provide documents since the system more appropriate to be used by the lower and intermediate management, for instance executives, engineers etc. In any organizations, without support and interest from the management, it is very difficult for capturing the corporate memory which defined as valuable assets if no funding and allocation will be injected, thus, jeopardizing the future of the corporate memory.

\section{REFERENCES}

[1] Stein, J.C. 2013. Origins, Measurement, and Policy Responses. A Research Symposium sponsored by the Federal Reserve Bank of St. Louis.

[2] Frost, A. 2010. Organizational Memory and Knowledge Repositories" retrieved from www.knowledge-management-tools.net

[3] Pettersson, U. 2015. Success and Failure Factors for KM: The Utilization of Knowledge in the Swedish Armed Forces. Journal of Universal Computer Science, 15 (8), 1735-1743.

[4] Rajender, K., Kumar, K.P. 2013. Knowledge Management Practices in SME Sector An Empirical Study. International Journal of Business and Management Tomorrow, 2 (4), 1-9.

[5] Storey, C., Kahn, K.B. 2010. The Role of Knowledge Management Strategies and Task Knowledge in Stimulating Service Innovation . Journal of Service Research,13 (4), 397- 410.

[6] Yaghoubi, N.M., Maleki, N. 2012. Critical Success Factors of Knowledge Management (A Case Study: Zahedan Electric Distribution Company). J. Basic Appl. Sci. Res., 2 (12), 12024-12030.

[7] Yip, M.W., Ng, A.H.H., Lau, D.H.C. 2014. Employee Participation: Success Factor of Knowledge Management. International Journal of Information and Education Technology, 2 (3), 262.

[8] Cegarra-Navarro, J., Cepeda-Carrion, G., Jimenez-Jimenez, D. 2010. Linking Unlearning with Innovation through Organizational Memory and Technology. Electronic Journal of Knowledge Management, 8 (1), 1 - 10.

[9] de Vasconcelos, J.B., Kimble, C., Rocha, A. 2013. Organisational Memory Information Systems An example of a Group Memory System for the Management of Group Competencies. J. UCS, 9 (12), 1410-1427.

[10] Weiner, B.J. 2009. A theory of organizational readiness for change. Implementation Science, 4, 67.

[11] Frost, M.A. 2014. A Synthesis of Knowledge Management Failure Factors.Sc., retrieved from www.knowledge-management-tools.net

[12] Hamid, N.A.A., Salim, J. 2011. A Conceptual Framework of Knowledge Transfer in Malaysia EGovernment IT Outsourcing: An Integration with Transactive Memory System (TMS). IJCSI International Journal of Computer Science Issues, 8 (3-5), 51-64.

[13] Supardal, Cipto, B., Nurmandi, A., Pribadi, U., Suranto. 2017. Do information communication technology initiatives affect local government bureaucratic transformation. International Journal of Applied Business and Economic Research, 15.

[14] Pettersson, U. 2017. Improved Safety Science - utilizing a Design Hierarchy. Paper presented at ICKM 2017 : 19th International Conference on Knowledge Management on January, 19-20, 2017 at London, United Kingdom. World academy of Science, Engineering and Technology, 11 (1), 273-278. 